\title{
PENTINGNYA PSIKOLOGI PENDIDIKAN BAGI GURU
}

\author{
Rudi Haryadi $^{1}$ dan Cindi Cludia ${ }^{2}$ \\ ${ }^{1,2}$ Pendidikan Fisika, Universitas Sultan Ageng Tirtayasa \\ Jl. Raya Jkt Km 4 Pakupatan, Panancangan, Kecamatan Cipocok Jaya, Kota Serang 42124 \\ ${ }^{1}$ Email: rudiharyadi@untirta.ac.id \\ ${ }^{2}$ Email: cindicludia01@gmail.com
}

\begin{abstract}
ABSTRAK
Pembelajaran psikologi pendidikan berarti mempelajari aspek psikologis siswa agar guru memiliki aturan dasar untuk menerapkan teknik pembelajaran yang efektif yang diterapkan pada karakteristik siswa tertentu. Keterampilan belajar juga melibatkan strategi-strategi yang dikomunikasikan dalam pembelajaran, terlepas dari apakah siswa dapat memahaminya dengan baik atau tidak.Dalam proses mendidik,seorang guru diharapkan dapat menghadapi tantangan dalam mengevaluasi karakteristik yang berbeda dari setiap siswa. Dalam psikologi pendidikan, guru akan memahami perbedaan kepribadian siswa dalam pembelajaran dan bagaimana menghadapi perbedaan kepribadian tersebut, sehingga dengan mempelajari psikologi pendidikan yang baik,guru dapat mengetahui perbedaan karakter siswa dan tidak bingung dalam menghadapinya. Dalam psikologi pendidikan, banyak sekali pembahasan tentang masalah-masalah yang berkaitan dengan perkembangan manusia. Oleh karena itu, guru tidak hanya dapat mengajar mata kuliah tematik di dalam kelas, tetapi juga memberikan pengarahan atau bimbingan kepada siswa yang membutuhkan masalah akademik. Selain memberikan solusi bagi siswa yang memiliki permasalahan akademik, guru juga dapat menjalin ikatan sosial dengan siswa sehingga tercipta suasana yang positif dalam kegiatan pembelajaran.
\end{abstract}

Kata Kunci: Psikologi, Pendidikan, Siswa, Guru.

\begin{abstract}
Educational psychology learning means studying the psychological aspects of students so that the teacher has basic rules for applying effective learning techniques that are applied to certain student characteristics. Learning skills also involve communicated strategies in learning, regardless of whether students understand them well or not. In the educational process, a teacher is expected to face challenges in evaluating the different characteristics of each student. In educational psychology, the teacher will understand the differences in student personalities in learning and how to deal with these personality differences, so that by studying good educational psychology, the teacher can know the differences in student character and not be confused in dealing with them. In educational psychology, there is a lot of discussion about problems related to human development. Therefore, teachers can not only teach thematic subjects in the classroom, but also provide direction or guidance to students who need academic problems. In addition to providing solutions for students who have academic problems, teachers can also build social bonds with students so as to create a positive atmosphere in learning activities.
\end{abstract}

Keyword: Psychology, Education, Students, Teachers.

\section{PENDAHULUAN}

Psikologi pendidikan merupakan ilmu yang sangat penting yang harus dikuasai oleh seorang guru sebagai pendidik dan pengajar. Sebagai pendidik, guru harus memahami semua aspek perilaku atau karakter siswa agar dapat menjalankan tugas dan perannya. Pendidikan tidak dapat dipisahkan dari psikologi. Pengetahuan psikologis tentang siswa 
sangat penting dalam pendidikan. Oleh karena itu penguasaan ilmu psikologi harus menjadi prasyarat bagi calon guru.

Psikologi pendidikan merupakan mata pelajaran yang sangat penting yang harus dimiliki oleh seorang guru atau pendidik untuk membantunya memahami perilaku belajar siswa, untuk menemukan solusi dari masalah yang sedang dihadapi, dan menjelaskan apakah siswa dalam keadaan belajar yang baik. Namun pada prinsipnya psikologi pendidikan merupakan alat yang penting untuk memahami perilaku belajar siswa. Psikologi pendidikan merupakan alat bagi guru untuk mengontrol dirinya sendiri, tetapi juga memberikan bantuan belajar bagi kegiatan belajar siswa untuk mencapai tujuan pendidikan itu sendiri.

Guru yang memiliki pemahaman yang baik tentang psikologi pendidikan akan mampu menciptakan suasana sosial dan emosional yang kondusif di dalam kelas sehingga siswa dapat belajar dengan nyaman dan bahagia. Pemahaman guru tentang psikologi pendidikan dapat memungkinkan untuk berinteraksi dengan siswa secara lebih bijak, penuh empati dan lebih perhatian serta menjadi karakter yang menarik di hadapan siswa. Pada hakikatnya pendidikan adalah proses melatih siswa. Agar formasi ini efektif dan berhasil, pendidik harus memiliki kualifikasi atau keterampilan dalam psikologi pendidikan.

Konsep dasar psikologi pendidikan biasanya merupakan sub disiplin ilmu psikologi yang mempelajari masalah-masalah psikologis dalam pendidikan, kemudian masalah tersebut diselesaikan dalam bentuk konsep, teori dan metode. Psikologi pendidikan juga menjelaskan tentang ciri-ciri pembelajaran adaptif atau pola yang disesuaikan berdasarkan usia (perkembangan kognitif).

Tujuan keseluruhan dari pembelajaran psikologi pendidikan adalah sebagai berikut:

1. Tujuan mempelajari psikologi dalam pendidikan adalah untuk memahami dan memperkuat proses pembelajaran.

2. Mengembangkan pengetahuan dan metode pembelajaran proses mengajar dalam situasi sehari-hari yang sesuai dengan usia dalam lingkungan pendidikan.

3. Dalam proses pembelajaran atau proses belajar mengajar, biasanya siswa memahami bentuk gejala psikologis yang berupa tingkah laku dan sikap.

4. Memahami kemampuan dan potensi siswa dalam proses pembelajaran.

5. Memahami bagaimana melakukan proses pengajaran untuk mencapai semua tujuan pembelajaran secara efektif dan terbaik. 
6. Membantu siswa menyelesaikan rencana pembelajaran materi dengan sempurna, sehingga pemahaman guru tentang teori psikologi pendidikan dan sains dapat memberikan bantuan $100 \%$ kepada siswa untuk menyelesaikan rencana pembelajaran.

Menurut psikologi dunia, manfaat psikologi pendidikan bagi pendidik adalah sebagai berikut:

1. Peka terhadap perilaku manusia dan perlu belajar.

2. Mengatasi masalah yang muncul dikalangan siswa.

3. Memahami gejala yang ditimbulkan siswa dalam proses mengajar.

4. Mengembangkan diri, menjadi manusia pembelajar, dan mampu berbagi pengetahuan dengan orang lain secara profesional.

5. Mengetahui teknik yang tepat untuk memaksimalkan potensi belajar siswa.

6. Mampu menganalisis kelebihan dan kekurangan metode belajar mengajar diri sendiri dan orang lain, serta berusaha untuk terus melakukan perbaikan.

Manfaat belajar psikologi pendidikan bagi siswa antara lain:

1. Meningkatkan kemauan dan kemauan untuk mencari dan memperoleh pengetahuan.

2. Kenali insting dan potensi belajar.

3. Kembangkan diri Anda sebagai manusia pembelajar.

4. Bertekad untuk meningkatkan harga diri lebih baik dari generasi sebelumnya.

Jika usia siswa kurang dari 5 tahun, maka metode pembelajarannya adalah belajar sambil bermain, begitu juga jika sudah berusia remaja dapat digunakan metode diskusi kelompok.Dengan demikian, melalui pembelajaran psikologi pendidikan, pendidik akan menyadari dan memahami bahwa peran nyata mereka adalah membuat siswa ingin dan tahu bagaimana cara belajar, bukan dengan memberikan informasi sebanyak mungkin, tetapi dengan membuat siswa ingin mencari informasi sebanyak mungkin dalam kegiatan.

\section{METODE PENELITIAN}

Metode yang dilakukan dalam penelitian ini adalah metode observasi. Metode observasi adalah metode yang dilakukan dengan jalan mengadakan pengamatan terhadap tingkah laku peserta didik dalam situasi yang wajar, dilaksanakan dengan berencana, kontiniu dan sistematik serta diikuti dengan upaya mencatat atau merekam secara lengkap.

Dalam lingkup yang lebih khusus, terutama dalam konteks kelas dapat dipakai seorang guru dengan maksud untuk melihat makna dari suatu tindakan atau apa yang berada di balik tindakan seseorang. Karena sumber data utama dalam penelitian ini adalah kata-kata dan tindakan. Dengan demikian, penggunaan suatu metode penelitian dapat 
mengantarkan peneliti memahami suatu makna di balik tindakan seseorang. Metode ini sering dipahami sebagai cara atau jalan yang ditempuh seseorang dalam melakukan suatu kegiatan berkaitan dengan pikologi belajar, dipakai untuk mengumpulkan berbagai data dan informasi penting yang bersifat psikologis dan berkaitan dengan proses pembelajaran.

\section{HASIL DAN PEMBAHASAN}

\section{Pengertian dan Definisi Psikologi Pendidikan}

(A. Sujanto,1985:1) menyatakan bahwa Pengertian dan definisi Psikologi Pendidikan dapat dilihat dari dua sudut yakni etimologi dan terminologi. Menurut etimologi (asal usul kata) Psikologi Pendidikan dapat dijabarkan dalam dua kata yakni "Psikologi" dan "Pendidikan". Psikologi pertama secara etimologi adalah istilah hasil peng-Indonesia-an dari bahasa asing, yakni bahasa Inggeris "Psychology". Istilah psychologi sendiri bersal dari kata kata Yunani "Psyche", yang dapat diartikan sebagai roh, jiwa atau daya hidup, dan "logis" yang dapat diartikan ilmu. Kedua secara terminologi (istilah) maka psikologi berarti ilmu jiwa atau ilmu yang memperlajari atau menyelidiki pernyataan-pernyataan.

Pendidikan yang berasal dari kata didik dalam bahasa Indonesia juga hasil dari transeletasi peng-Indonesia-an dari bahasa Yunani yaitu "Peadagogie". Etimologi kata Peadagogie adalah "pais" yang artinya "Anak", dan "again" yang terjemahannya adalah "bimbing". Jadi terjemahan bebas kata peadagogie berarti "bimbingan yang diberikan kepada anak". Menurut termonologi yang lebih luas maka pendidikan adalah usaha yang dijalankan oleh seseorang atau sekelompok orang lain agar menjadi dewasa atau mencapai tujuan hidup dan penghidupan yang lebih tinggi dalam arti mental (Sudirman N,1992:4).

Penelusuran makna dua kata psikologi dan pendidikan di atas dapat dijadikan dasar untuk melihat lebih jauh pengertian dan definisi psikologi pendidikan. Dengan maksud untuk memahami lebih luas psikologi dan pendidikan dari sudut masing masing, berikut beberapa definisi Psikologi Pendidikan yang pernah dikemukakan para ahli.

Menurut Crow \& Crow; Educational psychology deseribesa and explains the learning experiencess of an individual from birth though old age. Its subject matter is concerned with the conditions that efect learning (Crow \& Crow, 1958:7). Crow \& Crow menegaskan bahwa Psikologi merupakan suatu ilmu yang menerangkan masalah belajar pada seorang anak sejak lahir sampai usia lanjut, termasuk didalamnya kondisi yang mempengaruhi belajar. Kemudian Barlow memberikan batasan Psikologi Pendidikan sebagai berikut:.... a body of knowladge grounded in psychological research which 
provides a repertioire of resoucers to aid you in functioning more effectively in teaching learning process (Barlow:1985).

Makna dari kutipan tersebut adalah bahwa Psikologi Pendidikan sebagai sebuah pengetahuan berdasarkan riset psikologi dengan rangkaian sumber sumber untuk membantu anda melaksanakan tugas tugas sebagai guru dalam proses belajar mengajar secara efektif.

Bagian berikut ini Witherington menegaskan pengertian Psikologi Pendidikan sebagai berikut: A Systematic study of the process and factor involvidin the education of human being called educational psychology (Witherington:1952). Terjemahan Indonesianya adalah bahwa Psikologi Pendidikan merupakan studi sistematis tentang proses proses dan faktor-faktor yang berhubungan dengan manusia.

\section{Pentingnya Psikologi Pendidikan}

Bidang pendidikan membutuhkan pengetahuan tentang psikologi, karena bidang pendidikan dihadapkan pada karakteristik perilaku, kepribadian, sikap, minat, motivasi, perhatian, persepsi, kemampuan berpikir, kecerdasan, fantasi, dan aspek psikologis lainnya yang bervariasi dari siswa ke siswa. Agar proses pembelajaran berhasil, setiap guru di kelas yang berperan sebagai pendidik dan pengajar harus memahami perbedaan karakteristik psikologis siswa. Dengan memahami karakteristik psikologis setiap siswa, maka guru sekolah akan dapat melakukan pembelajaran yang dipersonalisasi berdasarkan karakteristik psikologis peserta didik. Oleh karena itu, sifat heterogenitas (tidak sama) suatu kelas perlu menjadi perhatian utama bagi guru. Selain pembelajaran yang bersifat individual, guru perlu juga melakukan pembelajaran secara kelompok jika karakteristik psikologis peserta didik yang ada di suatu kelas dianggap relatif sama (homogen).

Dalam proses pembelajaran di kelas, guru sering menghadapi siswa dengan disabilitas perhatian, sehingga perhatian siswa tersebut untuk mengikuti proses pembelajaran di kelas menjadi lemah, dan mengakibatkan rendahnya prestasi akademik siswa tersebut. Gejala gangguan atensi merupakan faktor psikologis yang dialami siswa di dalam kelas, hal tersebut harus dikenali dan dipahami oleh guru sebagai pengajar dan pendidik di kelas untuk mencegah dan mengatasi kesulitan belajar yang dihadapi siswa dalam proses mengikuti pembelajaran di kelas. Guru di kelas dapat melakukan upaya pencegahan dan penanggulangan masalah attention deficit yang dihadapi siswa di kelas Guru hendaknya mengadopsi metode dan strategi pembelajaran yang menarik perhatian pembelajaran sehingga siswa dapat merasa sangat nyaman dari awal hingga akhir kelas. 
Dengan memahami psikologi pendidikan, diharapkan para guru dapat melewati pertimbangan psikologis:

1. Tetapkan tujuan pembelajaran dengan tepat.

Dengan pemahaman psikologi pendidikan yang tepat, diharapkan guru dapat lebih tepat dalam menentukan bentuk perubahan perilaku yang dibutuhkan sebagai tujuan pembelajaran. Misalnya dengan mencoba mengaplikasikan pemikiran Bloom pada klasifikasi perilaku pribadi dan mengaitkannya dengan teori pengembangan diri.

2. Pilih strategi atau metode pembelajaran yang tepat.

Diharapkan dengan memahami psikologi pendidikan yang sesuai, guru dapat menentukan strategi atau metode pembelajaran yang tepat dan mengaitkannya dengan karakteristik dan keunikan pribadi, jenis dan metode pembelajaran, serta tingkat perkembangan yang dialami siswa.

3. Memberi bimbingan bahkan memberikan konseling

Selain pembelajaran, tanggung jawab dan peran guru juga diharapkan dapat membimbing siswa. Tentunya dengan memahami psikologi pendidikan, diharapkan para guru dapat memberikan bantuan psikologis yang tepat dan benar melalui proses hubungan interpersonal yang penuh kehangatan dan keakraban.

4. Mempromosikan dan memotivasi pembelajaran siswa.

Promosi artinya bekerja keras mengembangkan segala potensi yang dimiliki siswa, seperti bakat, bakat dan minat. Sedangkan motivasi berarti mendorong siswa untuk melakukan tindakan tertentu, terutama tindakan pembelajaran. Tanpa pemahaman penuh tentang psikologi pendidikan, guru akan kesulitan untuk menunjukkan bahwa mereka adalah fasilitator dan promotor pembelajaran siswa.

5. Menciptakan suasana belajar yang menyenangkan.

Efek pembelajaran membutuhkan suasana belajar yang menyenangkan. Guru yang sangat memahami psikologi pendidikan dapat menciptakan suasana sosial dan emosional yang baik di dalam kelas sehingga siswa dapat belajar dengan nyaman dan bahagia.

6. Berinteraksi dengan siswa secara tepat.

Pemahaman guru tentang psikologi pendidikan memungkinkan untuk berinteraksi dengan siswa secara lebih bijak dan lebih pengertian serta menjadi karakter yang menarik di hadapan siswa. 
7. Menilai hasil belajar yang adil.

Pemahaman guru tentang psikologi pendidikan dapat membantu guru melakukan evaluasi yang lebih adil terhadap pembelajaran siswa dalam hal evaluasi teknis, realisasi prinsip evaluasi, dan penentuan hasil evaluasi.

Siswa yang menunjukkan sikap dan perilaku acuh tak acuh atau apatis dalam proses pembelajaran di kelas juga menunjukkan bahwa siswa tersebut mengalami ketidakmampuan belajar dan motivasi belajar yang rendah. Untuk mengatasi gejala rendahnya minat dan motivasi belajar yang ditunjukkan siswa di dalam kelas, faktor psikologis tersebut akan mempengaruhi proses pembelajaran dan kualitas siswa di kelas, guru harus mampu memilih dan menerapkan metode, strategi dan metode pembelajaran yang dapat dikembangkan untuk menuumbuhkan minat belajar dan motivasi belajar peserta di kelas.

Adapun strategi, metode dan metode pembelajaran yang dapat digunakan guru saat mengajar siswa dengan minat dan motivasi belajar rendah adalah metode Cara Belajar Siswa Aktif (CBSA) yang menggunakan Pendekatan Keterampilan Proses (PKP), pendekatan konstruktivistik, metode diskusi,metode pembelajaran koperatif, metode penemuan dan penyelidikan (discovery and inquiry learning), metode Contextual Teaching Learning (CTL), metode eksperimen,dan berbagai metode, strategi, dan pendekatan pembelajaran yang menuntut aktivitas belajar peserta didik dalam mengikuti proses pembelajaran di kelas, di laboratorium dan di tempat belajar lainnya.

Selain itu faktor strategi, pendekatan, dan metode pembelajaran perlu menjadi perhatian bagi guru, faktor karakteristik psikologis yang mencerminkan kepribadian dan perilaku peserta didik di kelas harus juga menjadi perhatian para guru untuk menyesuaikan pembelajarannya dengan karakteristik kepribadian dan perilaku yang dimiliki oleh para peserta didik agar proses pembelajaran yang dilakukan oleh guru sesuai dengan minat dan kebutuhan belajar peserta didik.

Disinilah pentingnya guru menerapkan proses pembelajaran yang di individualisasikan sesuai dengan minat dan kebutuhan belajar peserta didik secara individual. Masih banyak gejala-gejala gangguan psikologis yang ditunjukkan oleh peserta didik dalam mengikuti proses pembelajaran di kelas, misalnya gangguan pengamatan,gangguan persepsi, gangguan dalam berpikir, gangguan ingatan, gangguan fantasi,dan gangguan perasaan. gangguan-gangguan psikologis tersebut merupakan gejala atau aktivitas umum jiwa manusia (La Sulo,1990). Aktivitas umum jiwa manusia tersebut perlu diketahui dan dipahami oleh para guru dalam mengetahui dan memahami aspek 
psikologis para peserta didik di kelas agar proses dan hasil pembelajaran yang dikelola di kelas dapat mencapai tujuannya secara maksimal danoptimal.

Dari uraian di atas menunjukkan bahwa banyak masalah-masalah yang dihadapi oleh para guru dalam proses pendidikan di kelas. Masalah-masalah tersebut merupakan masalah psikologis peserta didik yang sangat mempengaruhi proses pembelajaran dikelas, sehingga perlu diketahui dan dipahami oleh para calon guru dan para guru yang telah mengajar dan mendidik di kelas. Oleh karena itu, mata kuliah Psikologi Pendidikan merupakan mata kuliah wajib dipelajari oleh para calon guru di lembaga pendidikan tenaga kependidikan atau tenaga keguruan berupa IKIP, FKIP, Fakultas Tarbiyah, IAIN/ UIN, STKIP dan lembaga keguruan lainnya.

Mata kuliah Psikologi Pendidikan bagi seorang calon guru dan guru merupakan dasar pengetahuan yang mendasari profesi mengajar. Guru sebagai pendidik dan pengajar yang memiliki pengetahuan tentang Psikologi Pendidikan akan mampu mengembangkan serta menerapkan prinsip-prinsip psikologi dalam membelajarkan dan mendidik peserta didik di kelas. Pengetahuan guru tentang belajar dan syarat-syarat keberhasilan aktivitas pembelajaran di kelas memungkinkan guru dapat memilih, merencanakan, dan mengevaluasi proses mengajar atau proses pembelajaran dan mengevaluasi hasil dari proses pembelajaran sebagai suatu sistem yang terkait satu sama lain.Guru harus selalu kreatif dalam membelajarkan peserta didik di kelas dengan menerapkan pengetahuan tentang Psikologi Pendidikan secara optimal dan maksimal.

Proses pendidikan dan pembelajaran yang dilakukan oleh para guru tidak hanya berlangsung di dalam kelas di suatu lembaga pendidikan formal saja, melainkan proses pendidikan dan pembelajaran dapat berlangsung di lembaga pendidikan informal (di lingkungan keluarga), dan di lembaga pendidikan non formal (dimasyarakat) atau dimana saja tanpa dibatasi oleh ruang, waktu, dan tempat. Namun, perlu diketahui, dipahami, dan disadari bahwa ada syarat-syarat yang harus dipenuhi bagi berlangsungnya proses pendidikan dan pembelajaran di suatu tempat, yaitu adaguru sebagai pendidik dan pengajar yang telah dewasa, ada peserta didik sebagai orang yang belum dewasa yang membutuhkan pendewasaan melalui proses pendidikan dan pembelajaran, adanya pemberian pengaruh yang disengaja dari gurukepada peserta didik, dan pengaruh yang diberikan oleh guru tersebut memiliki nilainormative (positif) dan tujuan positif mengembangkan kognitif, afek dan psikomotorik peserta didik.

Pendidikan memang tidak bisa dilepaskan dari psikologi. Sumbangsih psikologi terhadap pendidikan sangatlah besar. Kegiatan pendidikan, khususnya pada pendidikan 
formal, seperti pengembangan kurikulum, Proses Belajar Mengajar, sistem evaluasi, dan layanan Bimbingan dan Konseling merupakan beberapa kegiatan utama dalam pendidikan yang di dalamnya tidak bisa dilepaskan dari psikologi.

Pendidikan sebagai suatu kegiatan yang di dalamnya melibatkan banyak orang, diantaranya peserta didik, pendidik, adminsitrator, masyarakat dan orang tua peserta didik. Oleh karena itu, agar tujuan pendidikan dapat tercapai secara efektif dan efisien, maka setiap orang yang terlibat dalam pendidikan tersebut seyogyanya dapat memahami tentang perilaku individu sekaligus dapat menunjukkan perilakunya secara efektif.

Guru dalam menjalankan perannya sebagai pembimbing, pendidik dan pelatih bagi para peserta didiknya, tentunya dituntut memahami tentang berbagai aspek perilaku dirinya maupun perilaku orang-orang yang terkait dengan tugasnya, terutama perilaku peserta didik dengan segala aspeknya, sehingga dapat menjalankan tugas dan perannya secara efektif, yang pada gilirannya dapat memberikan kontribusi nyata bagi pencapaian tujuan pendidikan di sekolah.

\section{SIMPULAN}

Oleh karena itu, penguasaan terhadap ilmu psikologi pendidikan merupakan suatu tuntutan terhadap orang yang bergelut dalam dunia pendidikan sebagai salah satu keahlian pendidik.Sebab, seorang pendidik yang memiliki keahlian mendidik akan mampu membuat individu orang lain (siswa-siswi) belajar dan kualitas seorang pendidik memberi pengaruh terhadap peningkatan kompetensi peserta didik.

Arti penting Psikologi Pendidikan bagi guru. Penguasaan guru tentang psikologi pendidikan merupakan salah satu kompetensi yang harus dikuasai guru, yakni kompetensi pedagogik. Muhibbin Syah (2003) mengatakan bahwa "diantara pengetahuan-pengetahuan yang perlu dikuasai guru dan calon guru adalah pengetahuan psikologi terapan yang erat kaitannya dengan proses belajar mengajar peserta didik".

\section{DAFTAR PUSTAKA}

Bismi. 2017. Pentingnya Mempelajari Psikologi Pendidikan Bagi Calon Guru. https://steemit.com/indonesia/@bismi/pentingnya-mempelajari-psikologipendidikan-bagi-calon-guru

Education, ePsikologi Digital.2020. Psikologi Pendidikan: 5 Pengertian, Sejarah, Konsep Dasar, Teori, dan Ruang Lingkup. https://epsikologi.com/psikologi-pendidikan/

Lenox, Berlow Daniel.1985. Educational Psychology. Chicago: The Mody Bible Institute. 
Rahayu, Puji.2015. Apa Sih Pentingnya Guru Mempelajari Psikologi Pendidikan???. http://everydreamscometrue.blogs.uny.ac.id/2015/09/10/apa-sih-pentingnya-gurumempelajari-ilmu-psikologi-pendidikan/

Sudirman N. Dkk .1992. Ilmu Pendidikan. Bandung: Remaja Rosdakarya.

Sujanto, Agus.1985. Psikologi Perkembanga. Jakarta: Rajawali 